\title{
Video Article \\ IgY Technology: Extraction of Chicken Antibodies from Egg Yolk by Polyethylene Glycol (PEG) Precipitation
}

\author{
Diana Pauly ${ }^{1}$, Pablo A. Chacana ${ }^{2}$, Esteban G. Calzado ${ }^{3}$, Björn Brembs $^{4}$, Rüdiger Schade ${ }^{5}$ \\ ${ }^{1}$ Center for Biological Security, Robert Koch-Institute \\ ${ }^{2}$ CICVyA - INTA Castelar, Instituto de Virología \\ ${ }^{3}$ Center of Molecular Immunology, Ciudad de la Habana, Cuba \\ ${ }^{4}$ Department of Biology, Chemistry, Pharmacy, Institute of Biology-Neurobiology, Free University of Berlin \\ ${ }^{5}$ Institut of Pharmacology, Charité-University Medicine of Berlin
}

Correspondence to: Rüdiger Schade at ruediger.schade@charite.de

URL: https://www.jove.com/video/3084

DOI: doi:10.3791/3084

Keywords: Immunology and Infection, Issue 51, Immunization, Chicken, Antibodies, Polyethylene Glycol

Date Published: 5/1/2011

Citation: Pauly, D., Chacana, P.A., Calzado, E.G., Brembs, B., Schade, R. IgY Technology: Extraction of Chicken Antibodies from Egg Yolk by Polyethylene Glycol (PEG) Precipitation. J. Vis. Exp. (51), e3084, doi:10.3791/3084 (2011).

\section{Abstract}

Hens can be immunized by means of i.m. vaccination (Musculus pectoralis, left and right, injection volume $0.5-1.0 \mathrm{ml}$ ) or by means of Gene-Gun plasmid-immunization. Dependent on the immunogenicity of the antigen, high antibody-titres (up to 1:100,000 - 1:1,000,000) can be achieved after only one or 3 - 4 boost immunizations. Normally, a hen lays eggs continuously for about 72 weeks, thereafter the laying capacity decreases. This protocol describes the extraction of total lgY from egg yolk by means of a precipitation procedure (PEG. Polson et al. 1980). The method involves two important steps. The first one is the removal of lipids and the second is the precipitation of total lgY from the supernatant of step one. After dialysis against a buffer (normally PBS) the IgY-extract can be stored at $-20^{\circ} \mathrm{C}$ for more than a year. The purity of the extract is around $80 \%$, the total IgY per egg varies from $40-80 \mathrm{mg}$, dependent on the age of the laying hen. The total lgY content increases with the age of the hen from around $40 \mathrm{mg} / \mathrm{egg}$ up to $80 \mathrm{mg} / \mathrm{egg}$ (concerning PEG precipitation). The laying capacity of a hen per year is around 325 eggs. That means a total potential harvest of $20 \mathrm{~g}$ total $\mathrm{lg} Y / y e a r$ based on a mean $\mathrm{lg} Y$ content of $60 \mathrm{mg}$ total $\lg Y / \mathrm{egg}$ (see Table 1).

\section{Video Link}

The video component of this article can be found at https://www.jove.com/video/3084/

\section{Protocol}

\section{Protocol - IgY-extraction by means of PEG-precipitation}

Fig. 1 gives a schematic diagram of the IgY-extraction procedure (see Table 2). The protocol was first described in Polson et al. 1980. All steps should be performed using latex gloves.

1. The eggshell is carefully cracked and the yolk is transferred to a "yolk spoon" in order to remove as much egg white as possible.

2. The yolk is transferred to a filter paper and rolled to remove remaining egg white, then the yolk skin is cut with a lancet or a similar instrument (pipette tip). The yolk is poured into a $50 \mathrm{ml}$ tube and the egg volume is registered (V1).

3. Twice the egg yolk volume of PBS is mixed with the yolk $\left(\sum \mathrm{V} 1+\mathrm{V} 2\right)$, thereafter $3.5 \%$ PEG 6000 (in gram, pulverized) of the total volume is added and vortexed, followed by 10 min rolling on a rolling mixer. That step of the extraction procedure separates the suspension in two phases. One phase consists of "yolk solids and fatty substances" (original quotation of Polson et al. 1980) and a watery phase containing lgY and other proteins.

4. The tubes are centrifuged at $4^{\circ} \mathrm{C}$ for $20 \mathrm{~min}(10,000 \mathrm{rpm}$ according to $13,000 \mathrm{xg}$, Heraeus Multifuge $3 \mathrm{SR}+$, fixed angle rotor). The supernatant (V3) is poured through a folded filter and transferred to a new tube.

5. $8.5 \%$ PEG 6000 in gram (calculated according to the new volume) are added to the tube, vortexed and rolled on a rolling mixer as in step 3 .

6. Repeat step 4 with the difference that the supernatant is discarded.

7. The pellet is carefully dissolved in $1 \mathrm{ml}$ PBS by means of a glass stick and the vortexer. PBS is added to a final volume of $10 \mathrm{ml}(\mathrm{V} 4)$. The solution is mixed with $12 \%$ PEG 6000 (w/v, 1.2 gram) and treated as in step 3 (vortex, rolling mixer).

8. Repeat step 6 and dissolve the pellet carefully in $800 \mu$ I PBS (glass stick and vortex). Wait for the air bubbles to disappear and then transfer (pipette) the extract to a dialysis capsule. Rinse the tube with $400 \mu \mathrm{l}$ PBS and add the volume to the dialysis device (V5). (For preparation of dialysis devices and membranes see appendix.)

9. The extract is dialysed over night in $0.1 \%$ saline $(1,600 \mathrm{ml})$ and gently stirred by means of a magnetic stirrer. The next morning, the saline is replaced by PBS and dialysed for another three hours.

10. Thereafter the IgY-extract is pulled from the dialysis capsule by a pipette and transferred to $2 \mathrm{ml}$ tubes. The final volume is around $2 \mathrm{ml}$ (V6). 
11. The protein content $(\mathrm{mg} / \mathrm{mL})$ of the samples is measured photometrically at $280 \mathrm{~nm}(1: 50$ diluted with PBS) and calculated according to the Lambert-Beer law with an extinction coefficient of 1.33 for IgY (see Fig. 2), Fig. 4 shows the quality of the preparation (purity and recovery are around $80 \%$ ).

12. It is advisable to store the samples in aliquots at $-20^{\circ} \mathrm{C}$ (do not freeze the samples at $-70^{\circ} \mathrm{C}$ ).

13. The quality of the final preparations is analysed by simple SDS-PAGE as described in JoVE protocol http://www.jove.com/details.php? id $=1916$

\section{Appendix- before use the dialysis bag must be prepared in the following way according to the recommendations of the manufacturer:}

1. 20 dialysis bags are cut in pieces of $30 \mathrm{~cm}$ and given in a $2000 \mathrm{ml}$ glass beaker.

2. $1,750 \mathrm{ml}$ of a $5 \mathrm{mM}$ EDTA-solution are added.

3. A glass funnel is placed above the bags to ensure that the bags are covered by the EDTA solution. The solution is heated and boiled for 5 $\mathrm{min}$ (hot plate). The solution is decanted and the bags are washed three times with distilled water.

4. Once again $1,750 \mathrm{ml}$ EDTA-solution are added, boiled for $5 \mathrm{~min}$ and washed three times with distilled water as above.

5. Finally the dialysis bags are boiled for $10 \mathrm{~min}$ in distilled water and stored at $4^{\circ} \mathrm{C}$. Take out the dialysis bags by means of sterilized tweezers.

\section{Representative results}

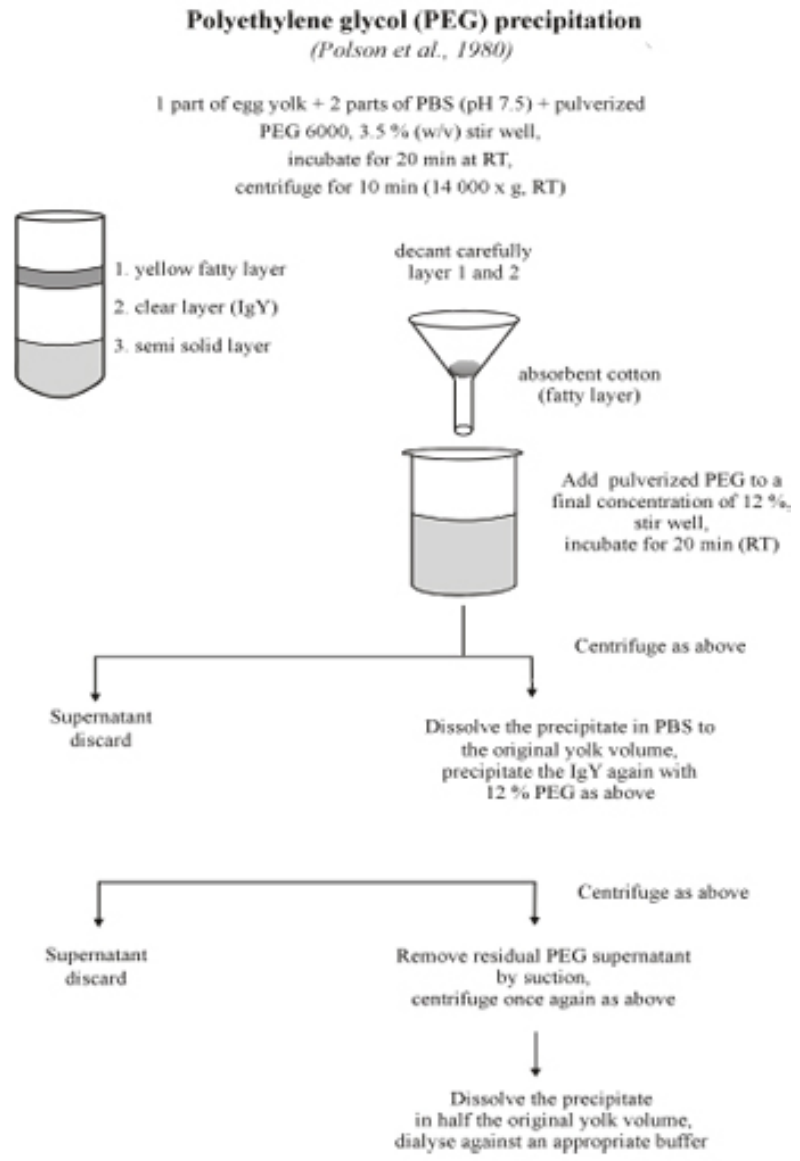

Figure 1. Schematic diagram of IgY-extraction by means of polyethylene glycol precipitation according to the original description of Polson et al. 1980. To view a larger image click here. 
Total IgY (weekly mean value of chicken $19 / 21 / 22 / 23$ )

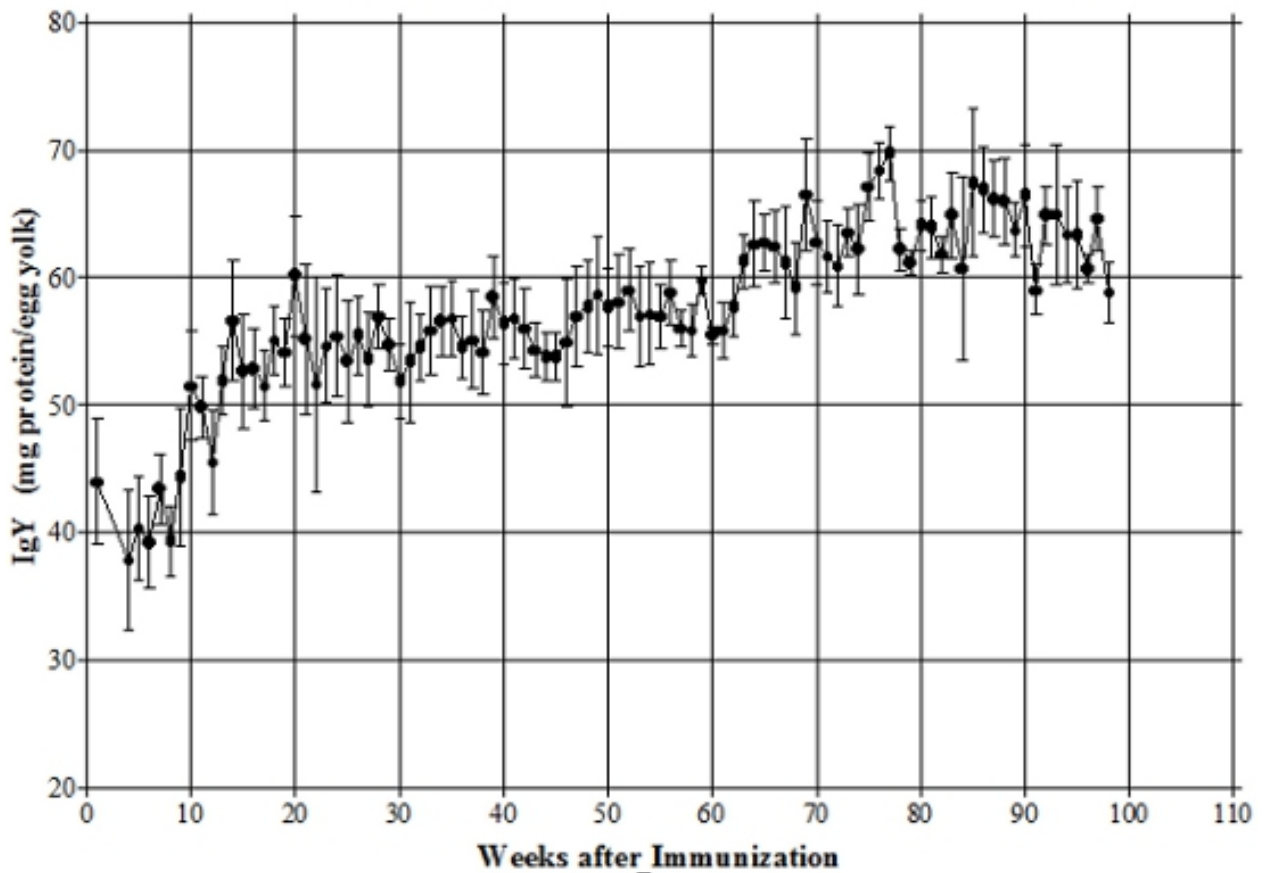

Figure 2. Development of total-lgY in egg yolk of immunised hens in dependence of age. Given is the weekly mean of total $\lg Y /$ egg and SD $(n=$ 4 laying hens). From [Pauly et al. 2009]).
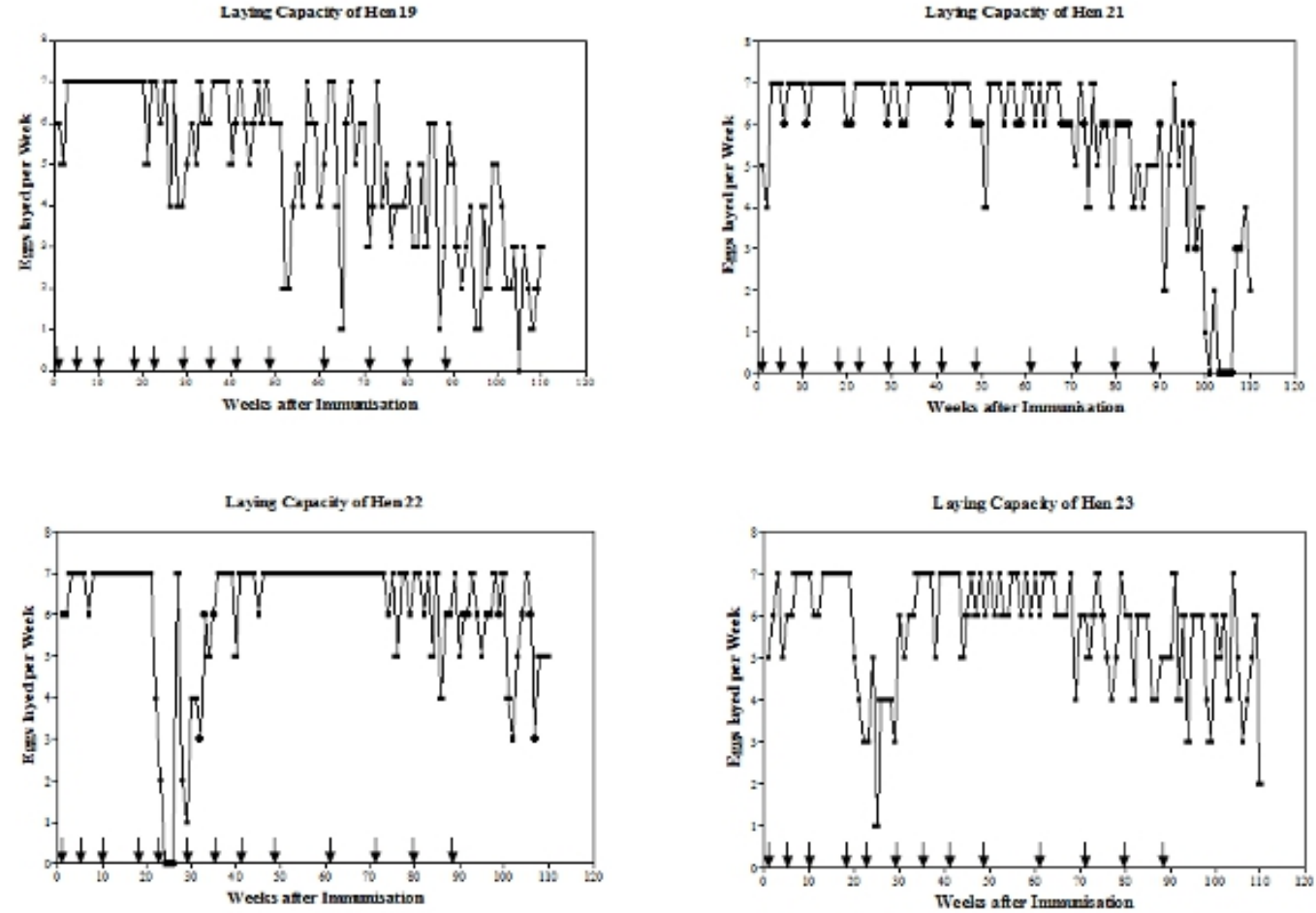

Figure 3. Laying capacity monitoring of four hens immunised with different antigens. The arrows indicate immunisation date (from [Pauly et al. 2009]). To view a larger image click here. 


\section{$\begin{array}{llllll}\mathrm{Mw}(\mathrm{kDa}) & 1 & 2 & 3 & 4 & 5\end{array}$}

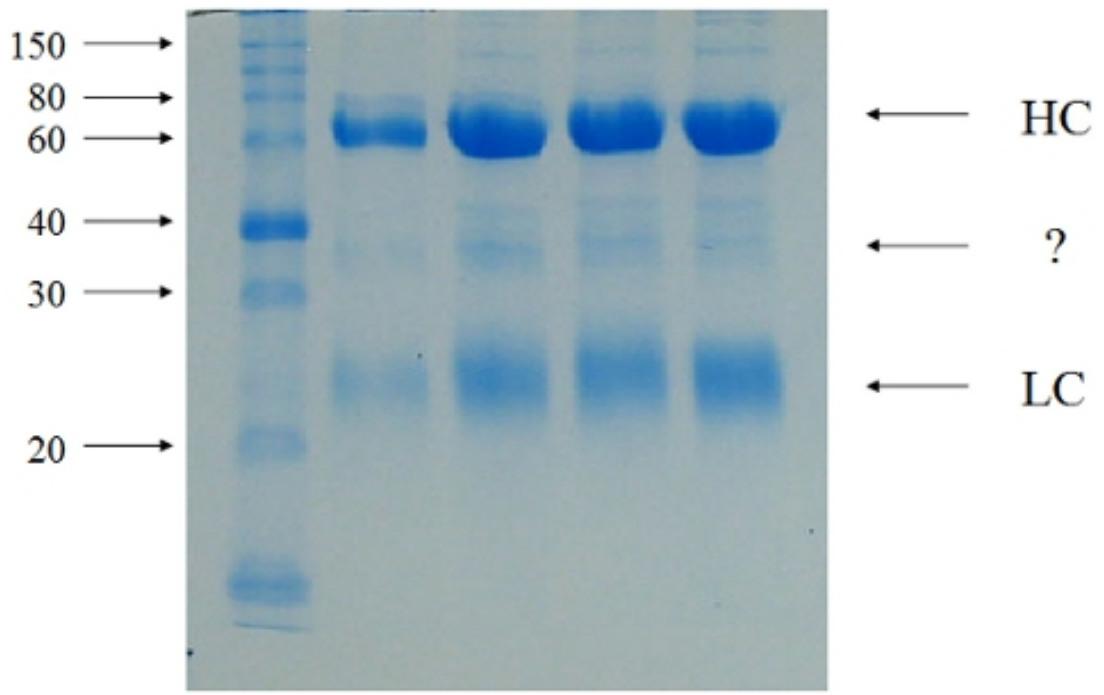

Figure 4. Polyacrylamide-Gelelectrophoresis of individual lgY preparations from different eggs under reducing conditions Lane 1 - Molecular weight marker, Lane 2 - IgY-standard, Lane 3-5 - different IgY samples prepared as described in the protocol. These are final preparations according to step 10 of the protocol. HC - heavy chains, LC - light chaines, ? - minor impurities corresponding to molecular weight around $35 \mathrm{kDa}$ (probably the C-terminal fragment of vitellogenin II precursor, [Klimentzou et al., 2006]).

\begin{tabular}{|l|l|l|l|l|}
\hline & Chicken 21 (Antigen A) & Chicken 22 (Antigen A) & Chicken 19 (Antigen B) & Chicken 23 (Antigen C) \\
\hline $\begin{array}{l}\text { Egg number (total IgY) }{ }^{1}, 2- \\
\text { years period }\end{array}$ & $625(38 \mathrm{~g})$ & $626(38 \mathrm{~g})$ & $545(33 \mathrm{~g})$ & $608(37 \mathrm{~g})$ \\
\hline $\begin{array}{l}\text { Egg number (total IgY), first } \\
\text { year }\end{array}$ & $345(20 \mathrm{~g})$ & $304(16 \mathrm{~g})$ & $326(18 \mathrm{~g})$ & $308(17 \mathrm{~g})$ \\
\hline $\begin{array}{l}\text { Egg number (total lgY), } \\
\text { second year }\end{array}$ & $280(18 \mathrm{~g})$ & $322(21 \mathrm{~g})$ & $219(15 \mathrm{~g})$ & $300(20 \mathrm{~g})$ \\
\hline $\begin{array}{l}\text { \% of max. possible egg } \\
\text { number (first year) }\end{array}$ & 106 & 93 & 100 & 95 \\
\hline $\begin{array}{l}\text { \% of max. possible egg } \\
\text { number (second year) }\end{array}$ & 86 & 99 & 67 & 92 \\
\hline number of processed eggs & 565 & 620 & 283 & 401 \\
\hline
\end{tabular}

${ }^{1}$ The amount of total $\lg Y$ is calculated by multiplying the number of eggs by a mean value of $60 \mathrm{mg}$ protein per egg according to the data of Figure 2.

${ }^{2}$ The max. possible egg number per year is 325 according to an information of the breeder.

Table 1. Two years statistics of egg laying capacity of chickens immunized with different antigens. Laying capacity in percent of the maximum of four hens after immunisation with different antigens as well as the IgY-outcome during two years (see also Fig. 3), [Pauly et al. 2009]).

\begin{tabular}{|c|c|c|c|c|c|c|c|c|c|c|c|c|}
\hline Egg Nr. & $\begin{array}{l}\text { Hen Nr. } \\
\text { Laying } \\
\text { Date }\end{array}$ & $\begin{array}{l}\mathrm{V} 1[\mathrm{ml}] \\
\text { yolk }\end{array}$ & \begin{tabular}{|l} 
V2[ml] \\
PBS
\end{tabular} & $\begin{array}{l}\text { 1. PEG } \\
\text { prec. [g] }\end{array}$ & $\begin{array}{l}\text { Vol [ml] } \\
\text { after }\end{array}$ & $\begin{array}{l}\text { 2. PEG } \\
\text { prec. [g] }\end{array}$ & Pellet & \begin{tabular}{|l} 
3. PEG \\
prec. [g]
\end{tabular} & Pellet & Vol [ml] & $\begin{array}{l}\text { Total } \\
\text { protein } \\
\mathrm{mg} / \mathrm{ml}\end{array}$ & $\begin{array}{l}\text { Corrected } \\
\text { total } \\
\text { protein } \\
\mathrm{mg} / \mathrm{ml}\end{array}$ \\
\hline & & & $\begin{array}{l}2 x \mathrm{~V} 1 \\
\sum \mathrm{V} 1+\mathrm{V} 2\end{array}$ & $\begin{array}{l}3,5 \%[\mathrm{w} / \\
\mathrm{v}] \sum \mathrm{V} 1+ \\
\mathrm{V} 2\end{array}$ & $\begin{array}{l}\text { prec., } \\
\text { centrif. } \\
\text { and } \\
\text { filtration } \\
\text { V3 }\end{array}$ & $\begin{array}{l}8,5 \%[\mathrm{w} / \\
\mathrm{v}] \mathrm{V3}\end{array}$ & \begin{tabular}{|l|} 
dissolved \\
in ml PBS \\
V4
\end{tabular} & $\begin{array}{l}12 \%[\mathrm{w} / \\
\mathrm{v}] \mathrm{V} 4\end{array}$ & $\begin{array}{l}\text { Dissolved } \\
\text { in ml PBS } \\
\text { V5 }\end{array}$ & $\begin{array}{l}\text { After } \\
\text { dialysis } \\
\text { against } \\
\text { PBS V6 }\end{array}$ & A280/ml & $\begin{array}{l}\text { A280/ } \\
\text { ml:1.33 }\end{array}$ \\
\hline 1 & $\begin{array}{l}\mathrm{H} 293 \text { / } \\
22.10 .\end{array}$ & 15 & 3045 & 1.58 & 31 & 2.63 & 10 & 1.2 & 1.2 & 1.7 & 35.0 & 26.3 \\
\hline 2 & $\begin{array}{l}\mathrm{H} 293 \text { / } \\
23.10 .\end{array}$ & 13 & 2639 & 1.37 & 25 & 2.12 & 10 & 1.2 & 1.2 & 1.7 & 28.8 & 21.6 \\
\hline
\end{tabular}

Table 2. Exemplary protocol of PEG precipitation 


\section{Discussion}

The choice of a suitable IgY purification method is influenced by scale of purification (laboratory or industrial), cost effectiveness, technology (laboratory equipment), and impact on the environment (waste management). Various IgY extraction methods were reviewed in detail by De Meulenaer \& Huyghebaert (2001, for review see also Schade et al. 2005). In general, these methods can be divided into three principal groups:

1. Precipitation methods: involving ammonium or sodium sulphate, polyethyleneglycol (PEG), caprylic acid and caragenean.

2. Chromatographic methods: affinity chromatography, ion exchange chromatography, hydrophobic interaction chromatography, thiophylic interaction chromatography, and gel-filtration chromatography.

3. Ultrafiltration.

The purity of an IgY preparation can be increased by a combination of methods; for example, PEG precipitation can be combined with affinity chromatography. In some instances, depending on the final application, a water extract of IgY is sufficient to achieve good results (Akita \& Nakai 1993). According to our experience, the IgY-sample we obtain by PEG-precipitation worked very well in a lot of different immunological assays. By standardizing the PEG-precipitation method one technical assistant is able to process approximately 84 eggs per week, which corresponds to an amount of total lgY between 4 and $7 \mathrm{~g}$ per week. A simple calculation: A laying hen is immunised with an antigen. After a few boost immunisations the hen produces specific antibodies (Ab) with a titre of 1:50,000 during a period of 30 days. 30 eggs $\times 2 \mathrm{ml}$ lgY extract (see protocol and Fig. 3) corresponds to $60 \mathrm{ml}$ total IgY, which in turn corresponds to an Ab-dilution of 3,000 I (the capacity of a bucket is $10 \mathrm{I}$ ), that means with 3,000 I of Ab solution 300 buckets can be filled. So, in view of such huge Ab-quantity it is no problem to store an Ab-pool of constant quality and specificity. This technique reduces the charge/lot variability otherwise observed in polyspecific Ab.

Despite of the aspect of quantity, IgY Ab have further advantages compared with mammalian IgG: No activation of mammalian complement system, no cross-reactivity with HAMA (human anti mouse antibody), rheumatoid factors or human blood group antigens (lack of heteroagglutinins).

An outstanding advantage of IgY-Ab is the so-called phylogenetic distance. Phylogenetic distance is the reason for the frequently described differences between the Ab specificities of mammals and chickens, even when identically immunised. In addition to differences between the mammalian and the avian immune system themselves, differences in phylogenetic development in these two animal classes contributes to the different $A b$ specificities. Several authors have reported that chickens often produce Abs against phylogenetically highly conserved mammalian proteins or peptides more efficiently than do rabbits (for review see Schade et a. 2005). As a consequence, a conserved antigen can remain"masked" to the rabbit immune system, and thus cause only a weak or a"silent" response. Furthermore, if chickens and rabbits are immunised with the same mammalian antigen, very often the chickens respond with an Ab-specificity that can rarely be achieved in rabbits. Also the aspect of animal welfare is important since the Ab are non-invasively extracted from egg yolk. In combination with Gene-Gun (plasmid) immunisation the IgY-production is completely non-invasive (Witkowski et al. 2009).

In conclusion, the production of $\mathrm{Ab}$ in hens and the IgY-extraction by means of PEG-precipitation is very cost-effective and results in highly specific Ab with stable titres up to 1:1,000,000. Due to the phylogenetic distance between Aves and Mammalia, chicken are able to produce specific Ab against highly conserved mammalian antigens in contrast to e.g. rabbits. The extraordinary amount of Ab obtained by lgY-technology opens the door also for using IgY-Ab in human- and veterinary medicine for therapeutic/prophylactic purposes.

\section{Disclosures}

Experiments on animals were performed in accordance with the guidelines and regulations set forth by Landesamt fur Gesundheit und Soziales Berlin (H 0069/03).

\section{Acknowledgments}

This work was supported by a grant from the German Federal Ministry of Education and Research (Project BiGRUDI [Biologische Gefahrenlagen: Risikobewertung, ultraschnelle Detektion und Identifizierung von bioterroristisch relevanten Agenzien, 13N9594]). We thank B. Diemar (Charité-Universitätsmedizin Berlin, Institut für Pharmakologie) for excellent technical assistance.

\section{References}

1. Akita, E.M. \& Nakai, S. Comparison of four purification methods for the production of immunoglobulins from eggs laid by hens immunized with an enterotoxigenic E. coli strain. J. Immunol. Methods 160, 207-214 (1993).

2. De Meulenaer, B. \& Huyghebaert, A. Isolation and purification of chicken egg yolk immunoglobulins: a review. Food Agricult. Immunol.13, 275 - 288 (2001).

3. Klimentzou, P., Paravatou-Petsotas, M., Zikos, Ch., Beck, A., Skopeliti, M., Czarnecki, J., Tsitsilonis, O., Voelter, W., Livaniou, E. \& Evangelatos, G.P.. Development and immunochemical evaluation of antibodies $Y$ for the poorly, immunogenic polypeptide prothymosin alpha. Peptides 27, 183-193 (2006).

4. Pauly, D., Dorner, M., Zhang, X., Hlinak, A., Dorner, B. \& Schade, R. Monitoring of laying capacity, immunoglobulin Y concentration, and antibody titer development in chickens immunized with ricin and botulinum toxins over a two-year period. Poultry Science 88, 281-290 (2009).

5. Polson, A., von Wechmar, M.B \& van Regenmortel, M.H. Isolation of viral IgY antibodies from yolks of immunized hens. Immunol. Commun. 9, 475-493 (1980).

6. Schade, R., Behn, I., Erhard, M., Hlinak, A. \& Staak C. Chicken egg yolk antibodies, production and application : IgY-Technology. Springer, Berlin. (2001). 
7. Schade, R., Calzado, E.G., Sarmiento, R., Chacana, P.A., Porankiewicz-Asplund, J. \& Terzolo, H.R. Chicken egg yolk antibodies (IgYtechnology): a review of progress in production and use in research and human and veterinary medicine. Altern. Lab Anim. 33, 129-154 (2005).

8. Witkowski, P.T., Bourquain, D.R., Hohn, O., Schade, R. \& Nitsche, A. Gene gun-supported DNA immunisation of chicken for straightforward production of poxvirus-specifiv IgY antibodies. J. Immunol. Methods 341, 146-153 (2009). 